\title{
海洋モデルによる温度成層の消長の再現性に関する検討
}

\section{A Study on Reproducibility of Thermal Stratification Using the Regional Ocean Modeling System}

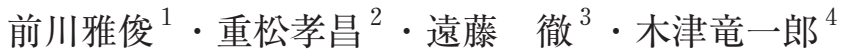 \\ Masatoshi MAEKAWA, Takaaki SHIGEMATSU, Toru ENDO and Ryuichiro KIZU
}

\begin{abstract}
Numerical simulation and field investigation were carried out to examine reproducibility of thermal stratification using Regional Ocean Modeling System. Water temperature distribution was measured in enclosed water area with weather information. As a result of numerical simulation, it is found that fluctuation of thermal stratification such as destruction caused by fierce wind and development caused by solar radiation can be reproducible. Furthermore, according to calculation results of kinematic viscosity coefficient, it was indicated destruction of thermal stratification was strongly influenced by wind stress.
\end{abstract}

\section{1. はじめに}

内湾の環境構造の推定・把握には, 潮汐変動, 河川を 通じた淡水流入量，気象要因としての日射量・風，等の 要因を考慮した海洋モデルが用いられる．閉鎖性の強い 内湾の環境構造は気象の影響を大きく受けるため，夏季 に発達する温度成層の影響を考慮した環境の評価は不可 欠であり，したがって，大気・海洋間の熱輸送の正確な 評価が求められる。しかし, 一般に海洋モデルで用いら れるバルクモデルの沿岸域とくに汽水域への適用性に関 する知見・検証例は少ない.

森ら（2007）は, 温度成層の崩壊の再現計算を行って いるが, 温度成層の消長の再現性を確認するための, 詳 細な水温と気象情報の観測及び再現計算は行っていな い.また, 森ら（2010）は, 沿岸域を対象に強風時の数 值実験を行い，バルクモデルによる風応力の再現性に関 する検討を行っているが，熱輸送に関する検討は行って いない.

そこで, 本研究では, 流動の影響の小さな水域を対象 として，水温の鉛直分布と気象情報を連続観測するとと もに，海洋モデルによってその再現計算を行うことによ って, 温度成層の消長の再現性を確認し, 計算結果から その消長に及ぼす要因について考察することをも目的と する.

$\begin{array}{llll}1 & \text { 正会員 } & \text { 修(工) } & \begin{array}{l}\text { Hitz日立造船(株) } \\ \text { 大阪市立大学大学院教授工学研究科 } \\ \text { 正会員 }\end{array} \\ \begin{array}{lll}\text { 都市系専攻 } \\ \text { 大阪市立大学大学院助教工学研究科 } \\ \text { 都市系専攻 } \\ \text { 大阪市立大学大学院工学研究科 } \\ \text { 都市系尃攻 }\end{array}\end{array}$

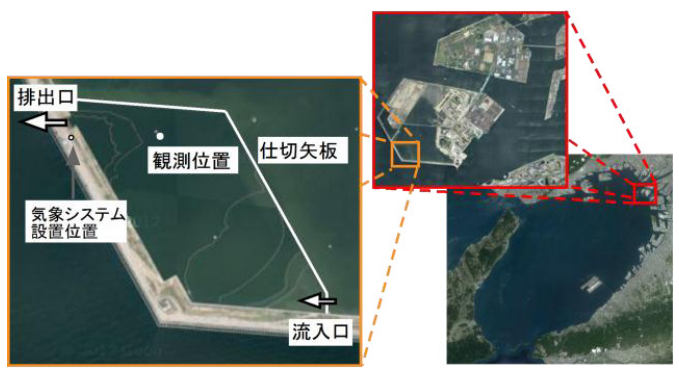

図-1＼cjkstart現地観測位置

\section{2. 研究の概要}

\section{（1）現地観測の概要}

現地観測は，大阪市此花区の埋立て造成地，夢洲内の 最終沈殿池において行った（図-1参照）。当地は，南北 約 $300 \mathrm{~m}$ ，東西約 $250 \mathrm{~m}$ ，平均水深約 $5 \mathrm{~m}$ の水域で，周囲を 護岸および矢板で仕切られた閉鎖性水域であり，流入口 を通じ他の池からの流入が，また，排出口より大阪湾へ の排水があるが, 観測期間中の有意な流入出はなかった. なお，観測期間は，2011年8月23日から9月28日までの 約 1 ケ月間であった.

観測項目は，水温の鉛直分布と気温・風向・風速・日 射量の気象情報であり，いずれも10分ごとに連続計測し た。水温は, 温度計 (Tidbit Temp Logger, Onset Computer 社製）を，水面直下，および，水面下 $0.5 \mathrm{~m}$ ま では $0.1 \mathrm{~m}$ 間隔で，0.5〜 $5.0 \mathrm{~m}$ では $0.5 \mathrm{~m}$ 間隔で懸垂して計 測した (図-2参照)。水面直下における水面温度（SST） の計測にあたっては，ブイの下に温度計を設置し，温度 計に，直接，日光が当たらないように工夫した。また， 沿岸気象観測システム（クリマテック（株）製）を設置 して, 気象情報を得た。気象観測システムの設置標高は, D.L.+14.248mであった。なお，観測開始時と終了時に は，多項目水質計（環境システム（株）製）を用いて， 
観測地点の水温と塩分の鉛直分布を計測した。

\section{（2）数値計算の概要}

海洋モデルは, Regional Ocean Modeling System （ROMS）を用いた．南北方向 $300 \mathrm{~m}$, 東西方向 $250 \mathrm{~m}$, 水 深 $5 \mathrm{~m}$ の水域を対象として, 気象条件のみを作用させて 計算を行うことによって, 現地観測水域の水温変化に着 目した計算を行った，計算にあたっては，水平方向には $5 \mathrm{~m}$ 間隔で，また，鉛直方向には $0.5 \mathrm{~m}$ 間隔で 10 層に分割 した.

現地観測開始時における水温掞よび塩分の鉛直分布 は，図-3の青色で示す曲線のようであった。すなわち， 現地水域では，水面下 $2.5 \sim 3.0 \mathrm{~m}$ に水温抄よび塩分の躍 層が形成されている。この観測結果に基づいて，計算の 初期条件として, 次式で表される水温および塩分の鉛直 分布を初期条件として与えて計算を行った。これらの式 で表される分布を，図-3の赤色で示す.

$$
\begin{aligned}
& T=21.6+7.2 \tanh [1.4(z+2.9)] \\
& S=21.69-2.4 \tanh [5.0(z+2.4)]
\end{aligned}
$$

計算に必要な気象情報は，現地にて観測した気温，風 向・風速，日射量を 10 分間隔で，また，気象庁大阪観測 所が観測した 10 分間隔の相対湿度，雲量，降水量を入力 し, 大気海洋間の運動量・熱・塩分フラックスを推定し,

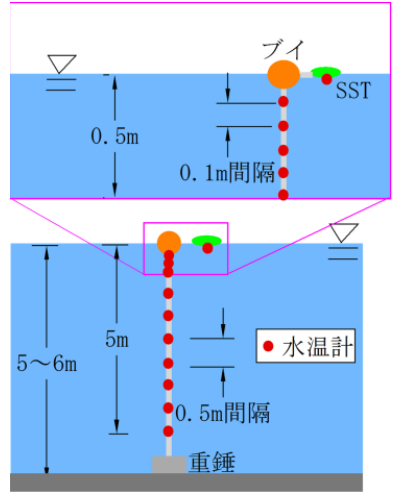

図-2 観測概要
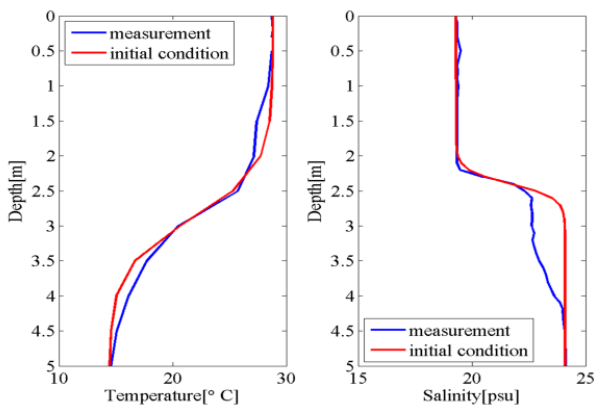

図-3 水温と塩分の初期条件
海面境界条件として与えた。運動量・顕熱・潜熱・塩分 フラックスは，COARE-2.5バルクアルゴリズム，長波放 射フラックスについては Berliand（1952）の式，短波放 射フラックスは，全天日射量のデータから，アルベド （日射反射率）を用いて算出した。アルベドの設定值に ついては議論の余地がある（例えば，東ら（2008）は 0.06として計算している）が，ここでは石川ら（2005） に倣って，0.1とした。

また，乱流モデルには，Mellor-Yamada level 2.5 モデル を用いた。

\section{3. 検討結果}

気象庁による観測期間中の降水量を，図-4に示す．同 図によれば，8月27日には極めて大きな降水量があるこ と，9月2日〜4日にかけては台風12号による，また，9 月21 22日にかけては台風 15 号による降水が観測されて いる。このほかに，9月17日に有意な降水量が観測され ている.

図-5は，現地に設置した気象観測システムによる風速， 気温，日射量の観測結果を示したものである。台風 12 号 および台風 15 号の接近に伴って, 風速のピークが観測さ れていること，抢よび気温・海水面温度が低下している 様子，さらには，日射量が低くなっている様子がわかる. 特に, 水面温度は, 日中の気温あるいは日射の影響を受 けて上昇し，風あるいは日射の影響を受けて顕著に下降 する様子を見て取ることができる。

図-6は，水温の鉛直分布の経時変化を示したものであ

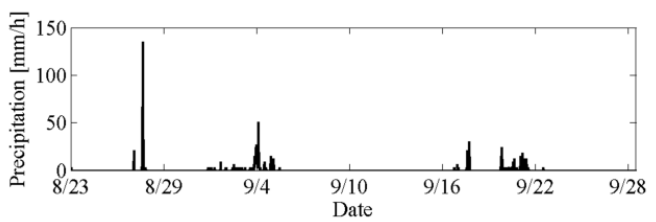

図-4 降水量

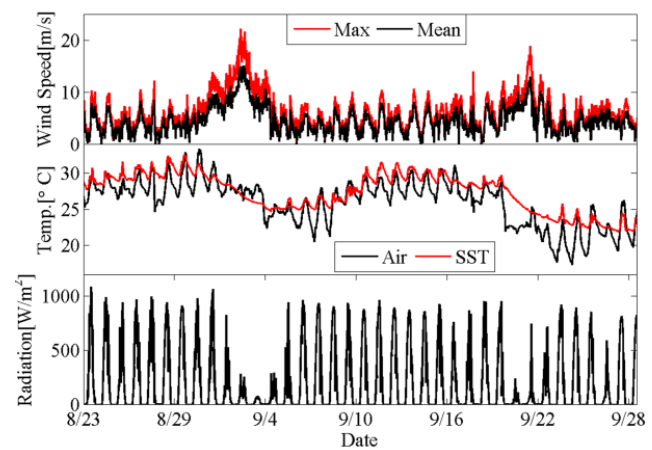

図-5 気象情報の観測結果（上から風速，気温，日射量） 

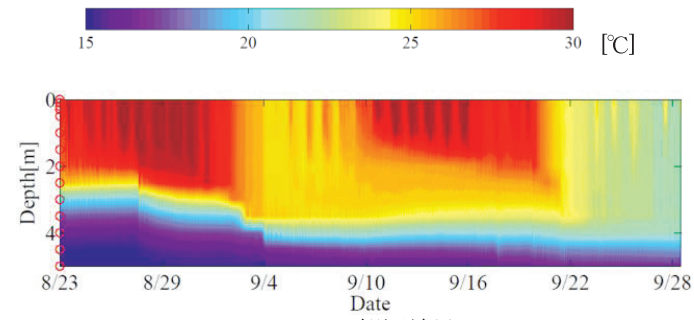

(a) 観測結果

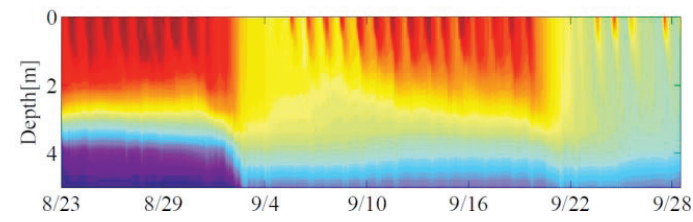

(b) 計算結果

図-6 水温の鉛直分布の経時変化

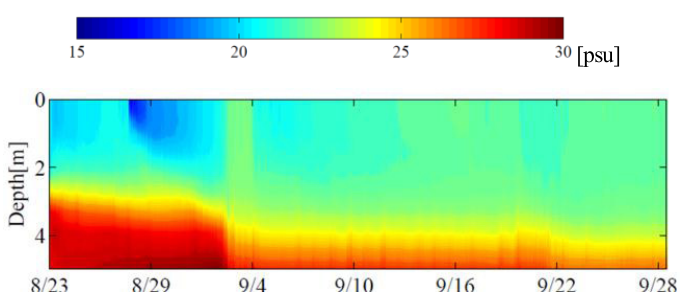

図-7 塩分の鉛直分布の経時変化（計算結果）

る。同図（a）は観測結果を，同図（b）はROMSによる 計算結果を示している。同図（a）によれば，観測期間 を通して, 水底付近の水温は $15 \sim 16{ }^{\circ} \mathrm{C}$ 程度と低く, 観 測開始時にはこの低温層が比較的厚い状態であったが, 降水あるいは台風が通過するごとに低温層厚が薄くなっ ていることがわかる。また，9月2日〜4日にかけての台 風 12 号の通過時には水温の鉛直混合が生じて温度成層が 減衰し, その後, 徐々に表面付近の温度が上昇するとと もに強固な温度成層が再形成される様子が，さらには， 9月 22 日の台風接近時に強風の影響を受けて再消滅した 後には，観測開始時に見られるような大きな温度成層は 再形成されていないことがわかる，一方，同図（b）の 計算結果は，観測結果に見られるようなシャープな温度 成層の再現はできていないものの，9月2日〜4日の台風 通過時の温度成層の減衰，その後の再形成，9月 22 日の 台風通過後の水温の鉛直分布など，気象擾乱に伴う水 温の鉛直分布の変化を良好に再現できていると判断さ れる。

図-7は，塩分の鉛直分布の経時変化を示している．同 図に示される計算結果によれば，8月28日の大量の降水 によって水面下 $1 \mathrm{~m}$ 程度の塩分は急激に低下するものの, 数日で徐々に水底方向に拡散し, 台風による強風の下で,

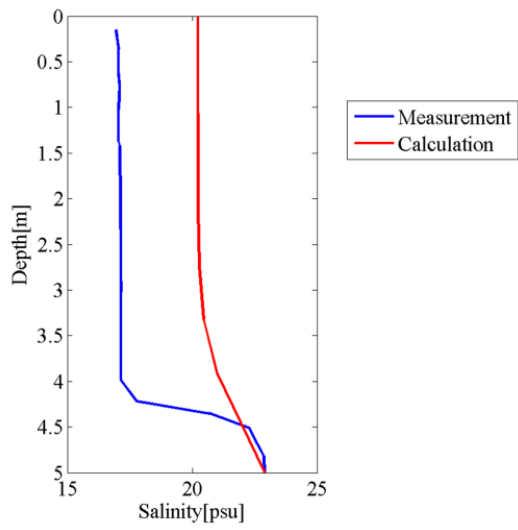

図-8＼cjkstart塩分の鉛直分布の再現性（9月28日）

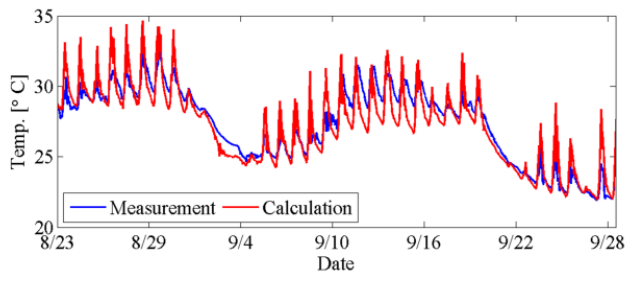

図-9 水面温度の比較

水面下約 $4 \mathrm{~m}$ 程度はほぼ均一な塩分となっている。図-8 は，9月28日に観測した塩分の鉛直分布を，計算結果と 共に示したものである。同図によれば，塩分の観測值は， 水面下 $4 \mathrm{~m}$ 程度までは約 $17 \mathrm{psu}$ と一定で水面下約 $4 \mathrm{~m}$ に明 瞭な躍層が見られることが分かる。一方，塩分の計算結 果は, 水面下約 $3.5 \mathrm{~m}$ までは約 $20 \mathrm{psu}$ で一定值を取り，そ の後，水底に至るまで漸増している，水底では，両者は ほぼ同じ值を有していることが分かる。図-3に示す 8 月 23 日の塩分の鉛直分布あるいは計算の初期条件と比較す ると，上層塩分の観測值は低下しており，塩分躍層の位 置は低下していることが分かる．さらに，水底における 塩分も低下していることがわかる，一方，図-8に示す計 算結果と図-3を比較すると, 躍層の位置が低下している こと，水底における塩分が低下していることは観測結果 と同様な傾向を示しているものの，上層の塩分は初期值 と大きな変化が見られないことが分かる．ROMSでは， 降水による水面における塩分フラックスを

$$
K_{s} \frac{\partial S}{\partial z}=(E-P) S
$$

として与えている。ここに, $E$ は蒸発量, $P$ は降水量, $K_{s}$ は鉛直方向の拡散係数である。式（3）は，水表面セル 内の液相の体積の増減から当該セルの塩分を決定するこ とを意味している.ここで対象としているような閉鎖的 な水域では，表層セル内の流動および鉛直混合が極めて 小さいと推定されるので，降水の混合が過剰に評価され 


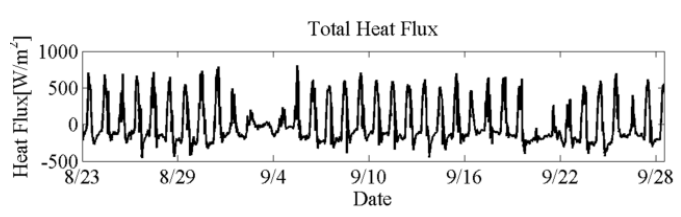

(a) 全熱フラックス

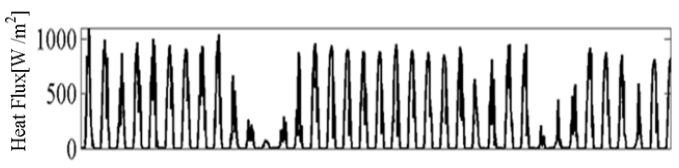

(b) 短波放射フラックス

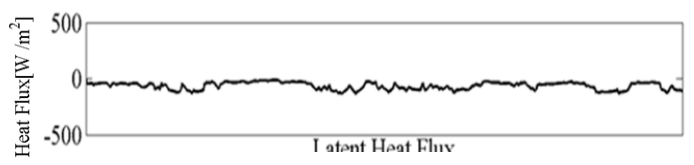

(c) 長波放射フラックス

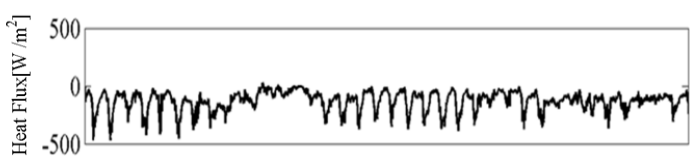

（d）潜熱フラックス

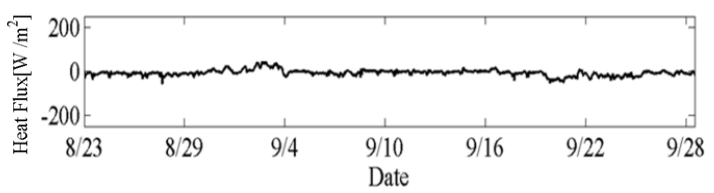

（e）顕熱フラックス

図-10大気海洋間の熱フラックスの時間変化

てしまい, その結果として表層の塩分が実際よりも高く 推定されるため, 図-8のような計算值と実測值との差が 現れているのではないかと考えられる。この他に, 観測 值と計算值が十分に再現されない要因として, 計算対象 水域への他の池からの流入水の影響や，水底を介した浸 透水の影響などが考えられる.

図-9は，水面温度の観測結果と計算結果を比較したも のである、計算における水面温度は最上層セルの值を示 しているが，七ルの厚みが $0.5 \mathrm{~m}$ であるので水面下 $0.25 \mathrm{~m}$ における水温を示していると考えられる，一方，観測值 の水面温度は, 水面下約 $2 \sim 3 \mathrm{~cm}$ における観測值である. 平均水面温度の観点から同図を見れば，台風通過時に温 度が低下する過程や, 温度成層が再形成される時期にお ける水温が上昇していく過程は, 良好に再現できている と判断される。一方, 日変動の観点から図-9を見ると, 計算による日変動は観測值と比較すると大きいことがわ かる。図-5において, 日中の水面温度は気温とほぼ同様 な值を有していることを考慮すれば, 図-9に示される水 面の日最大值は過大評価されていると判断される.

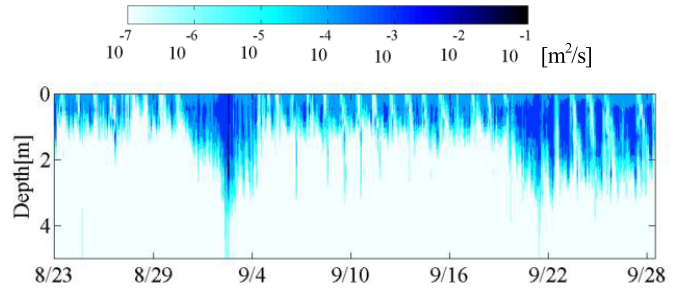

(a) 鉛直渦動粘性係数

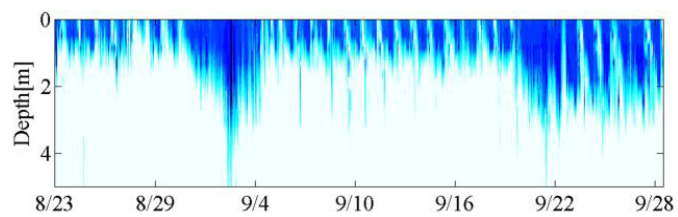

(b) 水温の鉛直渦拡散係数

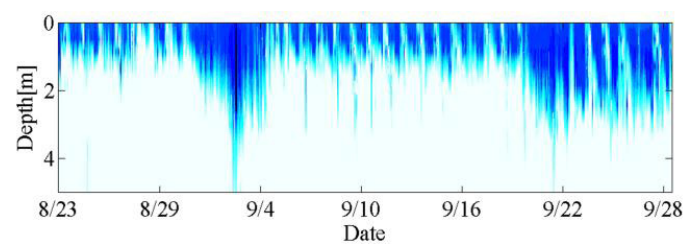

(c) 塩分の鈆直渦拡散係数

図-11 鉛直混合係数の時間変化

図-10は, 大気海洋間の大気海洋間の熱フラックス (大気から海洋の向きが正) の時系列変化を示したもの である。同図（a）は，大気海洋間の全熱フラックスを 示している. 同図（b）には短波放射フラックス, 同図 （c）には長波放射フラックス，同図（d)，（e）には，潜 熱および顕熱フラックスをそれぞれ示している. 8 月 27 日の降水は, 夕方の短時間イベントであったため, 長波 放射にはその影響はほとんど現れていない. 台風12号お よび台風 15 号の通過にともなう短波放射フラックスの減 少は著しく, 潜熱フラックスは, 成層が形成されている 時期および成層の再形成時には変動が大きく, 台風の通 過時および成層減衰期には変動が小さく, おおよそ0に 近い值をとっている，潜熱フラックスは，通常100〜 200W/m²である（たとえば，塚本（2002））ことを考える

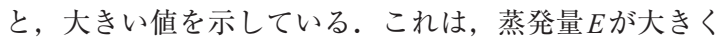
見積もられている可能性を示しており, 表層塩分の計算 精度との関連性も考えられる. また, 同図からは, 短波 放射フラックスと顕熱フラックスが海水面における熱フ ラックスに及ぼす影響が大きく，長波放射および潜熱フ ラックスは大きな影響を及ぼしていないことがわかる. これは，大阪湾を対象とした中村ら（1989）の推定と同 様の傾向を示している.

水面における熱収支の影響は, 風応力の作用を受けて 水面下へと伝播してゆく. 図-11 は, 鉛直渦動粘性係数 と, 水温および塩分の鉛直乱流拡散係数の時系列変化を 


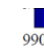

$\left[\mathrm{kg} / \mathrm{m}^{3}\right]$

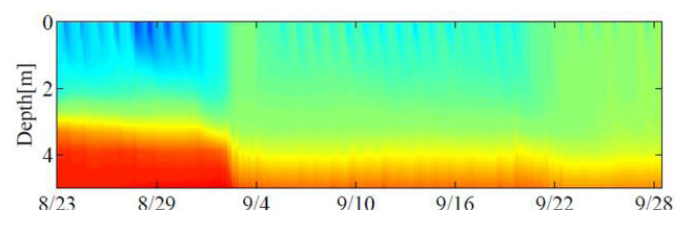

図-12 密度の時空間分布

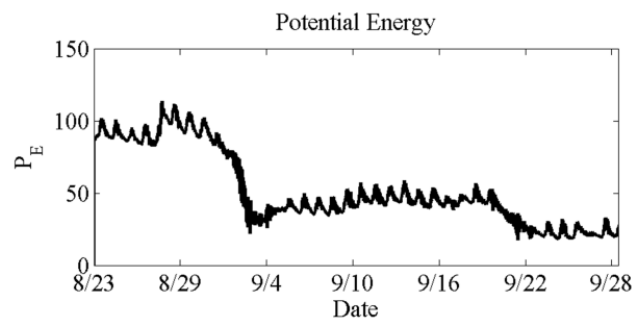

図-13 密度成層強度の時間変化

示したものである，同図から，いずれも係数も，2度の 台風通過時には水面から $4 \mathrm{~m}$ 程度にまでオーダーの大き な領域が見られ，温度成層および塩分成層の減衰には， 強風による鉛直混合が大きく影響したことが示唆されて いる.

図-12 は，計算によって求められた水温および塩分よ り密度を求め, その時・空間分布を示したものである. 同図によれば，台風12号の通過（9月2日〜4日）前後で， 密度成層の位置が，水面下約 $3 \mathrm{~m}$ から水面下約 $4 \mathrm{~m}$ 一と移 動していることが分かる．また，図-7の塩分の分布と比 較すると，密度は塩分に支配されていることが改めて認 識される。

多田ら（2010）は，密度成層の強度を表わす指標とし て, 次式で表されるポテンシャルエネルギー $P_{E}$ を提案し ている.

$$
P_{E}=\frac{1}{H} \int_{-H}^{0}(\rho-\bar{\rho}) g z \cdot d z
$$

ここに, $H$ は水深, $\rho$ は密度, $\bar{\rho}$ は密度の鉛直平均值, $g$ は重力加速度, $z$ は水表面から鉛直上向きに取った座標 であり， $P_{E}$ が大きいほど密度成層が強固であることを示 す。図-13は，式（4）を用いて求めたポテンシャルエネ ルギーPEの経時変化を示したものである. 台風 12 号の 通過に伴って， $P_{E}$ は急激に低下し，その後やや微増傾向 にあるが，台風 15 号の通過に伴って再び低下しているこ とがわかる。

\section{4. 結論}

本研究では，流動の影響の小さな閉鎖性水域を対象と して，一般に海洋モデルで用いられるバルクモデルによ
る, 温度成層の消長の再現性を確認するとともに, 計算 結果からその消長に及ぼす要因について考察を行った。 本研究で得られた結果を要約すると以下のようである.

（1）温度成層の消長の再現性

海洋モデルによる計算結果は，観測結果で見られた， 強風による鉛直混合作用に伴う温度成層の消滅，その 後の再形成，そして再びの強風による再消滅など，気 象擾乱に伴う水温の鉛直分布の変化を良好に再現でき ることが確認され，温度成層が発達する沿岸域への海 洋モデルの適用性に関する知見を得た。また，大気・ 海洋間の熱輸送を検討する上で重要な水面温度につい ても，強風時の鉛直混合に伴う水温低下，及び温度成 層再形成時の水温上昇などの過程を良好に再現できる ことがわかった。

（2）温度成層の消長に及ぼす要因

鉛直渦動粘性係数及び水温の鉛直渦拡散係数の計算結 果から，検討期間中の温度成層の減衰には，強風時の 全水深にわたる鉛直混合が大きく影響していることが 示唆された.

\section{参 考 文 献}

石川一郎 - 辻野博之 - 平原幹俊 - 中野英之 - 安田珠幾 - 石崎 廣 (2005): 気象研究所共用海洋モデル（MRI.COM）解説, 気像研究所技術報告，第47号，pp.1-189.

多田彰秀 - 中村康裕 · 阿部和也 - 田井 明 - 鈴木誠二 - 中村 武弘（2010）：淡水流入が諫早湾の水質動態に及ほす影響 について, 土木学会論文集 B2（海岸工学）,Vol.66, pp.366-370.

塚本 修（2002）：海面フラックスの季節変動に関する観測的 研究, 平成 13 年度京都大学防災研究所一般共同研究報告 書, $54 \mathrm{p}$

中村由行・一宮大祐・早川典生・西村 肇（1989）：長岡技術 科学大学研究報告, 第 11 卷, pp. 69-81.

東 博紀・牧 秀明 (2008):CIP-FEMを用いた準 3 次元内湾 流動モデルによる東京湾の循環流に関する基礎研究，水 工学論文集, 第 52 巻, pp. 1405-1410.

森 信人 · 大石智洋・中尾正喜 $\cdot$ 中井真由美・重松孝昌 $\cdot$ 矢 持 進 (2007) : 港湾内未利用エネルギー利用とこれに関 連する温度成層の特性把握に関する研究，海岸工学論文 集, 第54巻, pp.1316-1320.

森 信人・田中悠祐・間瀬肇・鈴木崇之・木原直人 (2011）:沿岸域における强風時の強鉛直混合についての数 值実験，土木学会論文集 B2（海岸工学）,Vol.67，No. 2, pp.321-325.

Berliand, M.E. and T.G. Berliand(1952): Determining the net longwave radiation of the Earth with consideration of the effect of cloudiness, ISV. Akad. Nauk. SSSR Ser. Geofiz. No.1.

Fairall, C.W., E. F. Bradley, D.P. Rogers, J.B. Edson and G.S. Young(1996): Bulk parameterization of air-sea fluxes for Tropical Ocean Global Atmosphere Coupled-Ocean Atmosphere Response Experiment, Journal of Geophysical Research, Vol.101, pp.3747-3764.

Shchepetkin A. F. • J. C. McWilliams (2005): The regional oceanic modeling system (ROMS): a split-explicit, free-surface, topography-following-coordinate oceanic model, Ocean Modeling 9, pp.347-404. 